\title{
KINERJA MESIN DIESEL MENGGUNAKAN BAHAN BAKAR SOLAR, DME DAN CAMPURANNYA DENGAN SIMULASI DINAMIKA FLUIDA
}

\author{
Taufik Yuwono dan Bambang Suwondo Rahardjo \\ Pusat Teknologi Pengembangan Sumberdaya Energi \\ BPPT Gedung II Lantai 22 JI MH Thamrin No.8 Jakarta 10340 \\ E-mail: tofu_ok@yahoo.com
}

\begin{abstract}
Fuel atomization plays a main role in determining the performance of diesel engines, where the spray pattern illustrates fuel combustion occurs in the combustion chamber. From fuel spray test results showed that fuel evaporation characteristics of fuel at a certain pressure will effect on engine performance. The higher the injection pressure will reduce the diameter of the fuel sprays (sauter mean diameter), thus speeding up evaporation and mixing processes between fuel and air in the combustion chamber with resulted the combustion process is more completely. Analysis of fuel atomization simulations performed at injection pressure 150, 180 and 235 bar on the distribution of size, temperature and concentration of air+fuel mixture. Physical chemical parameters resulting are the size and temperature distribution patterns fuel+air mixture sprays. DME is feasible to be used as alternative fuel in diesel engines by adding 2-5\% lubricant additives. The use of diesel+DME 50/50 mixed fuel provides the lowest fuel consumption by generating power of 3x2,975 watts.
\end{abstract}

Kata kunci: kinerja mesin, solar, DME, simulasi atomisasi, dinamika fluida

\section{PENDAHULUAN}

Upaya pengembangan bahan bakar alternatif sebagai pengganti bahan bakar minyak (BBM) menjadi tuntutan yang semakin menguat, di mana di-methyl ether (DME) saat ini sedang diproyeksikan sebagai salah satu sumber bahan bakar alternatif yang ramah lingkungan.

DME merupakan senyawa tidak beracun dan tidak mengandung sulfur $(\mathrm{S})$ dan nitrogen $(\mathrm{N})$, sehingga emisi (SOx, NOx, partikulat dan jelaga) jauh lebih rendah daripada diesel (solar) dan tidak merusak lapisan ozon. Selain itu, DME tidak korosif terhadap logam sehingga tidak memerlukan modifikasi khusus terhadap infrastruktur LPG yang ada jika digunakan sebagai pengganti atau pencampur LPG (A. Troy, Semelsberger, L. Rodney, Borup, L. Howard, Greene., 2006).

Cetane Number (CN) DME tinggi (55 60) sebagai ukuran kualitas pembakaran selama penyalaan kompresi, sehingga dapat digunakan bahan bakar pengganti solar [Constantine Arcoumanis, Choongsik Bae, Roy Crookes, Eiji Kinoshita, 2008].

Pemanfaatan DME berarti telah meningkatkan nilai ekonomisnya dan sebagai salah satu upaya mengurangi ketergantungan terhadap BBM sekaligus memecahkan masalah pencemaran lingkungan. Penggunaan DME sebagai bahan bakar pada mesin diesel membutuhkan modifikasi sistem injeksi yang sudah ada, karena adanya perbedaan karakteristik antara solar dan DME. Pembakaran DME tidak mengeluarkan jelaga karena mengandung oksigen dan struktur kimia tanpa membentuk ikatan-ikatan karbon.

Kelebihan yang dimiliki DME menunjukkan potensi menjadi bahan bakar alternatif pada mesin diesel, sedangkan kekurangannya untuk dapat diaplikasikan merupakan tantangan yang harus dijawab melalui pengujian.

Hasil pengujian sebelumnya (M.S. Boedoyo, Bambang S.R., Taufik Y., Wargiantoro P., Suharyono, 2010) menunjukkan adanya interaksi atau pengaruh tekanan injeksi bahan bakar (150 bar, 180 bar, 235 bar) dan sifat kimia fisik bahan bakar terhadap karakteristik atomisasi bahan bakar (solar, DME, dan campurannya), di mana semakin tinggi tekanan injeksi akan memperkecil ukuran butiran bahan bakar setelah injeksi, sehingga mempercepat penguapan dan pencampuran antara bahan bakar dan udara di dalam ruang bakar. Selain itu juga semakin tinggi kandungan DME maka jarak penetrasi kabutan 
akan semakin pendek, tingkat penguapan semakin cepat, sudut pengkabutan $\alpha$ semakin besar, proses pencampuran bahan bakar dan udara lebih sempurna sehingga pembakaran akan terjadi lebih sempurna, hal ini disebabkan oleh karena pembentukan uap lebih cepat dan lebih banyak pada awal pengkabutan.

\section{METODOLOGI}

Pengujian dilakukan di Laboratorium Balai Teknologi Motor dan Propulsi (BTMP), PUSPIPTEK, Serpong.

\subsection{Tujuan}

Melakukan uji kinerja mesin diesel berdasarkan mekanisme model simulasi atomisasi bahan bakar Solar, DME dan campurannya pada tekanan injeksi bahan bakar 150 bar, 180 bar dan 235 bar menggunakan piranti lunak CFD (Computational Fluid Dynamic) OpenFOAM.

\subsection{Bahan}

Tabel 1 dan Tabel 2 masing-masing menunjukkan karakteristik bahan bakar uji DME dan diesel (solar).

Tabel 1. Karakteristik DME

\begin{tabular}{|c|c|c|}
\hline Sifat Fisik & & DME \\
\hline Rumus kimia & & $\mathrm{CH}_{3}-\mathrm{O}-\mathrm{CH}_{3}$ \\
\hline Berat Molekul & $\mathrm{g} / \mathrm{mol}$ & 46 \\
\hline Kadar C & $\%$ mass & 52.2 \\
\hline Kadar $\mathrm{H}$ & $\%$ mass & 13 \\
\hline Kadar O & $\%$ mass & 34.8 \\
\hline Rasio $\mathrm{C} / \mathrm{H}$ & & 0.337 \\
\hline Suhu kritis & ${ }^{\circ} \mathrm{K}$ & 400 \\
\hline Tekanan kritis & $\mathrm{MPa}$ & 5.37 \\
\hline Densitas kritis & $\mathrm{kg} / \mathrm{m}^{3}$ & 259 \\
\hline Densitas cairan & $\mathrm{kg} / \mathrm{m}^{3}$ & 667 \\
\hline Relatif densitas gas (air=1) & & 1.59 \\
\hline Cetane number & & $>55$ \\
\hline Auto-ignition temperature & ${ }^{\circ} \mathrm{K}$ & 508 \\
\hline $\begin{array}{l}\text { Stoichiometric air/fuel mass } \\
\text { ratio }\end{array}$ & & 9.0 \\
\hline Titik didih pada $1 \mathrm{~atm}$ & ${ }^{\circ} \mathrm{K}$ & 248.1 \\
\hline Enthalpy penguapan & $\mathrm{kJ} / \mathrm{kg}$ & 467.13 \\
\hline Lower heating value (LHV) & $\mathrm{MJ} / \mathrm{kg}$ & 27.6 \\
\hline $\begin{array}{l}\text { Spesifik kapasitas panas } \\
\text { gas }\end{array}$ & $\mathrm{kJ} / \mathrm{kgK}$ & 2.99 \\
\hline Ignition limits & $\%$ Vol air & $3.4 / 18.6$ \\
\hline Modulus of elasticity & $\mathrm{N} / \mathrm{m}^{2}$ & $6.37 \mathrm{E}+0.8$ \\
\hline Kinematic viscosity of liquid & cSt & $<1$ \\
\hline Surface tension $\left(298^{\circ} \mathrm{K}\right)$ & $\mathrm{N} / \mathrm{m}$ & 0.012 \\
\hline Vapour pressure $\left(298^{\circ} \mathrm{K}\right)$ & $\mathrm{kPa}$ & 530 \\
\hline
\end{tabular}

Sumber: Elana M. Chapman, 2003
Tabel 2. Karakteristik diesel (solar)

\begin{tabular}{|c|c|c|}
\hline Sifat Fisik & & Diesel/Solar \\
\hline Rumus kimia & & - \\
\hline Berat Molekul & $\mathrm{g} / \mathrm{mol}$ & 170 \\
\hline Kadar C & $\%$ mass & 86 \\
\hline Kadar H & $\%$ mass & 14 \\
\hline Kadar O & $\%$ mass & 0 \\
\hline Rasio $\mathrm{C} / \mathrm{H}$ & & 0.516 \\
\hline Suhu kritis & ${ }^{\circ} \mathrm{K}$ & 708 \\
\hline Tekanan kritis & $\mathrm{MPa}$ & $3.00^{a}$ \\
\hline Densitas kritis & $\mathrm{kg} / \mathrm{m}^{3}$ & - \\
\hline Densitas cairan & $\mathrm{kg} / \mathrm{m}^{3}$ & 831 \\
\hline Relatif densitas gas (air=1) & & - \\
\hline Cetane number & & $40-50$ \\
\hline Auto-ignition temperature & ${ }^{\circ} \mathrm{K}$ & 523 \\
\hline $\begin{array}{l}\text { Stoichiometric air/fuel mass } \\
\text { ratio }\end{array}$ & & 14.6 \\
\hline Titik didih pada $1 \mathrm{~atm}$ & ${ }^{\circ} \mathrm{K}$ & $450-463$ \\
\hline Enthalpy penguapan & $\mathrm{kJ} / \mathrm{kg}$ & 300 \\
\hline Lower heating value (LHV) & $\mathrm{MJ} / \mathrm{kg}$ & 42.5 \\
\hline Spesifik kapasitas panas gas & $\mathrm{kJ} / \mathrm{kgK}$ & 1.7 \\
\hline Ignition limits & $\%$ Vol air & $0.6 / 6.5$ \\
\hline Modulus of elasticity & $\mathrm{N} / \mathrm{m}^{2}$ & $14.86 \mathrm{E}+08$ \\
\hline Kinematic viscosity of liquid & $\mathrm{cSt}$ & 3 \\
\hline Surface tension (at $298 \mathrm{~K}$ ) & $\mathrm{N} / \mathrm{m}$ & 0.27 \\
\hline Vapour pressure (at $298 \mathrm{~K}$ ) & $\mathrm{kPa}$ & $<<10$ \\
\hline
\end{tabular}

Sumber: Elana M. Chapman, 2003

\subsection{Peralatan}

Gambar 1 menunjukkan peralatan uji kinerja mesin diesel, yang terdiri dari tangki penyimpanan bahan bakar solar (1), DME (2) pada tekanan 5 bar, tabung gas $N_{2}$ (3) untuk memberi tekanan tambahan sampai minimal 12 bar pada tangki pencampuran (4), tangki pencampuran (4) bahan bakar solar dan DME secara sempurna.

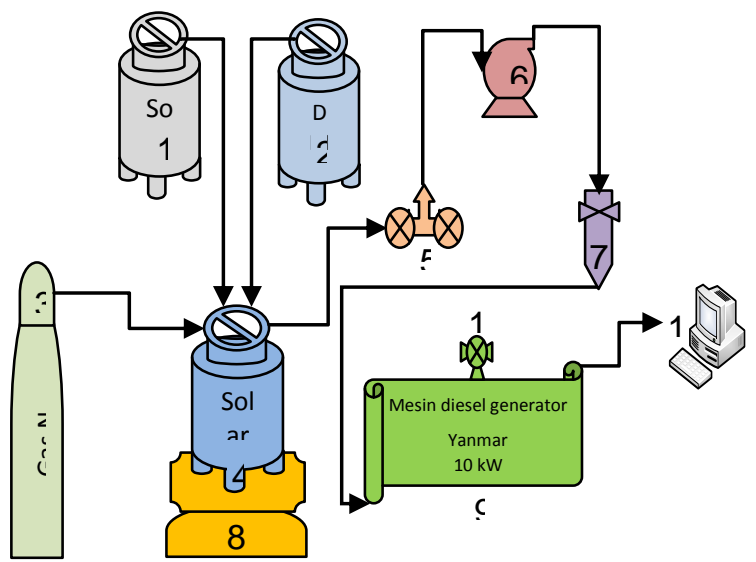

Gambar 1. Diagram alir proses peralatan uji kinerja mesin diesel 
Unit pengujian ini juga dilengkapi dengan pressure regulator (5) sebagai pengatur tekanan injeksi bahan bakar ke dalam mesin diesel melalui pompa (6) dan injektor (7). Injektor (7) berfungsi sebagai pemasok bahan bakar ke ruang bakar, di mana pengaturan tekanan injektor menggunakan cartridge test master pada kondisi 70 bar, 120 bar dan 185 bar.

Peralatan pendukung pengoperasian alat adalah imbangan elektronik (8) untuk mengetahui berat bahan bakar yang diinjeksikan ke dalam mesin diesel (9) dan mesin diesel generator Yanmar 10 KVA (9) dengan spesifikasi teknis seperti ditunjukkan pada Tabel 3 dan Tabel 4.

Tabel 3. Spesifikasi mesin diesel

\begin{tabular}{|c|c|c|}
\hline \multicolumn{2}{|c|}{ Parameter } & Data Teknis \\
\hline Jenis mesin & & $\begin{array}{c}\text { Diesel horizontal } 4 \\
\text { langkah } \\
\text { berpendingin air }\end{array}$ \\
\hline Sisten pembakaran & & direct injection \\
\hline Jumlah silinder & & 1 (satu) silinder \\
\hline Saat pengkabutan & & $19^{\circ}$ sebelum TMA \\
\hline Diameter $\times$ Stroke & $\mathrm{mm}$ & $110 \times 106$ \\
\hline Volume silinder & $\mathrm{cc}$ & 1007 \\
\hline Daya kontinyu & $\mathrm{dk} / \mathrm{ppm}$ & $16 / 2200$ \\
\hline Daya maksimum & $\mathrm{dk} / \mathrm{ppm}$ & $19 / 2200$ \\
\hline Torsi maksimum & $\mathrm{kgm} / \mathrm{ppm}$ & $7,42 / 1600$ \\
\hline Rasio kompresi & & 16,3 \\
\hline $\begin{array}{l}\text { Konsumsi bahan } \\
\text { bakar }\end{array}$ & gr/dk.jam & 1,79 \\
\hline Pompa bahan bakar & & Tipe Bosch \\
\hline Tekanan injektor & $\mathrm{kg} / \mathrm{cm}^{2}$ & 200 \\
\hline Kapasitas tangki & liter & 13,7 \\
\hline $\begin{array}{l}\text { Kapasitas minyak } \\
\text { pelumas }\end{array}$ & liter & 3,6 \\
\hline $\begin{array}{l}\text { Jenis minyak } \\
\text { pelumas }\end{array}$ & & $\begin{array}{c}\text { SAE } 40 \text { kelas CC } \\
\text { ata CD }\end{array}$ \\
\hline Sistem pendinginan & & Radiator \\
\hline $\begin{array}{l}\text { Kapitas tangki } \\
\text { pendingin }\end{array}$ & liter & 4,0 \\
\hline
\end{tabular}

Sumber: Hyun Kyu Suh, Chang Sik Lee, 2007

Tabel 4. Spesifikasi generator

\begin{tabular}{|c|c|c|}
\hline Parameter & & Data Teknis \\
\hline Merk & & Denyo \\
\hline Model & & $F A-12.5 F$ \\
\hline Output & KVA & 12,5 \\
\hline Phase & & $3 / U-V-W$ \\
\hline Tegangan & Volt & 380 \\
\hline Arus & Ampere & 19 \\
\hline Frekuensi & $\mathrm{Hz}$ & 50 \\
\hline Faktor Daya & & 0,8 \\
\hline Rating & & Continuous \\
\hline Speed & rpm & 1500 \\
\hline Berat & $\mathrm{kg}$ & 155 \\
\hline
\end{tabular}

Sumber: Hyun Kyu Suh, Chang Sik Lee, 2007

\subsection{Metode}

Pelaksanaan pengujian dalam rangka penelitian ini mengikuti tahapan proses maupun langkahlangkah kerja yang telah menjadi standar operasi prosedur (SOP) dengan penjabaran sebagai berikut.

Langkah pertama operasi adalah mengalirkan bahan bakar dari tangki penyimpanan bahan bakar solar (1) dan atau DME (2) menggunakan selang melalui pressure regulator ke dalam tangki pencampuran (4). Selanjutnya dicampurkan bahan bakar solar dan DME secara sempurna di dalam tangki pencampuran (4). Pada saat ini diberikan tekanan tambahan dengan membuka katup regulator gas pada tabung $\mathrm{N}_{2}$ (3) sampai tekanan di dalam tangki pencampuran (4) minimal 12 bar untuk menghindari kavitasi pada injector nozzle (7) agar aliran bahan bakar lancar.

Setelah itu katup tangki pengalihan dibuka untuk mengalirkan bahan bakar ke mesin diesel (posisi katup di bagian bawah tangki) dan membuka katup aliran bahan bakar yang berada di mesin diesel itu sendiri sehingga bahan bakar masuk ke pompa injeksi (6). Mesin diesel dihidupkan pada kondisi putaran mesin $1500 \mathrm{rpm}$ dan tunggu \pm 10 menit untuk memanaskan mesin sampai putaran stabil. Perangkat instrumen dihubungkan seperti ampermeter, voltmeter, smoke analyzer (11), timbangan elektronik (8) diaktifkan, dan disiapkan stopwatch untuk mengetahui waktu pengambilan data.

Pengambilan data di mulai saat menghidupkan stopwatch yang secara bersamaan membuat "nol" timbangan elektronik agar dapat diketahui konsumsi bahan bakar per 5 menit.

Data pengujian yang diambil adalah tegangan ( $\mathrm{R}, \mathrm{S}, \mathrm{T}, \mathrm{U})$, arus listrik (Ampere), konsumsi bahan bakar $(\mathrm{kg})$, emisi jelaga per 5 menit selama 1 jam.

\section{HASIL DAN PEMBAHASAN}

Parameter dan kondisi pemodelan simulasi dari hasil atomisasi bahan bakar solar, DME dan campurannya pada tekanan injeksi 150, 180 dan 235 bar ditunjukkan pada Tabel 5.

Simulasi numerik adalah beberapa pola parameter kimia fisik atomisasi bahan bakar sejak saat permulaan injeksi bahan bakar hingga pada saat interaksi dengan udara saat berakhirnya proses atomisasi. Parameter kimia fisik yang dihasilkan merupakan pola distribusi ukuran dan temperatur kabut campuran bahan bakar+udara. 
Tabel 5. Parameter dan kondisi simulasi

\begin{tabular}{|l|l|}
\hline Parameter & Kondisi \\
\hline Posisi & $(00.0995 \quad 0)$ \\
\hline Arah & $(0-10)$ \\
\hline Diameter & $0.00019 \mathrm{~m}$ \\
\hline Cd & 0,9 \\
\hline Masa & $6 \mathrm{e}-06$ \\
\hline Temperatur & $298^{\circ} \mathrm{K}$ \\
\hline Tekanan & $150,180,235$ bar \\
\hline Laju aliran masa & $(00.1272)$ \\
& $(4.16667 \mathrm{e}-056.1634)$ \\
& $(8.33333 \mathrm{e}-059.4778)$ \\
\hline
\end{tabular}

\subsection{Hasil}

Gambar 2 dan Gambar 3 masing-masing menunjukkan pola distribusi ukuran dan temperatur kabut 100\%Solar dengan 100\%DME pada tekanan 150 bar selama waktu injeksi 0,0015 detik.
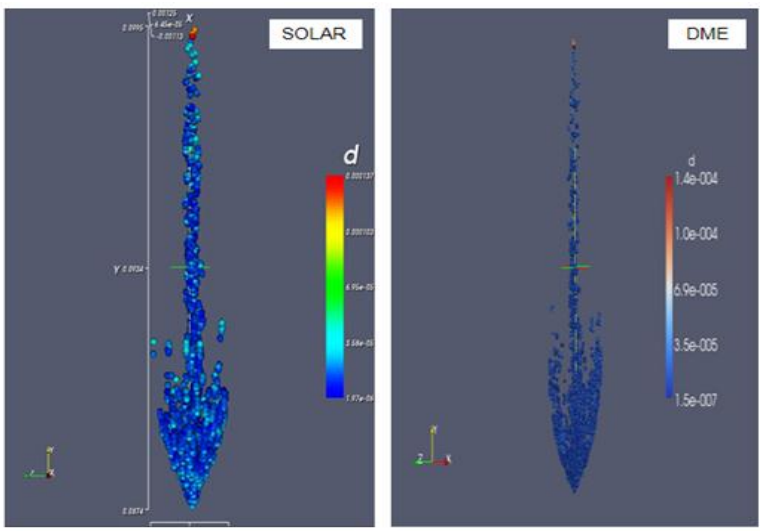

Gambar 2. Pola distribusi ukuran kabu $100 \%$ Solar dan 100\%DME $(0,0015$ detik, 150 bar $)$
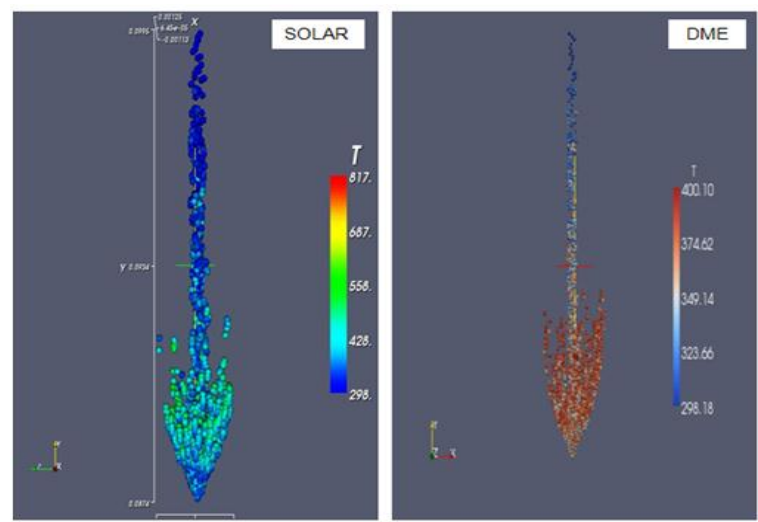

Gambar 3. Pola distribusi temperatur kabut $100 \%$ Solar dan $100 \%$ DME $(0,0015$ detik, 150 bar)

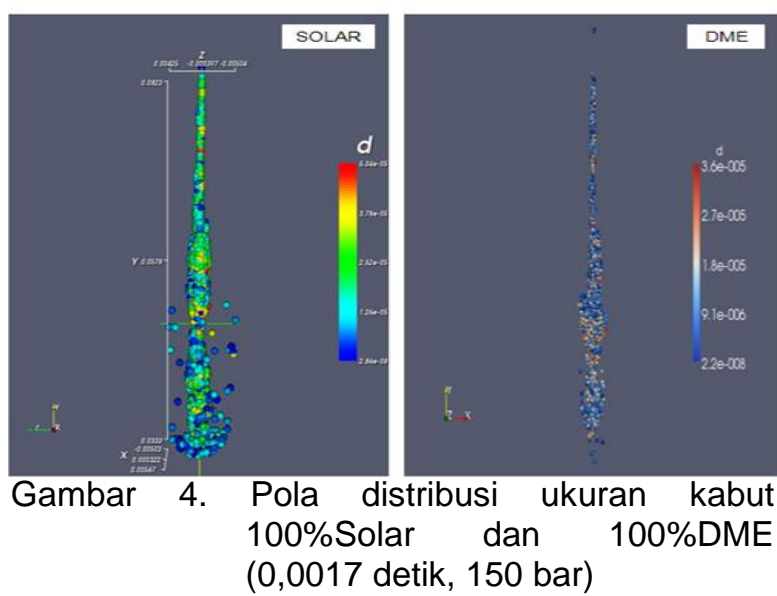

Gambar 4 dan Gambar 5 masing-masing menunjukkan pola distribusi ukuran dan temperatur kabut $100 \%$ solar dengan $100 \% \mathrm{DME}$ pada tekanan 150 bar selama waktu injeksi 0,0017 detik.

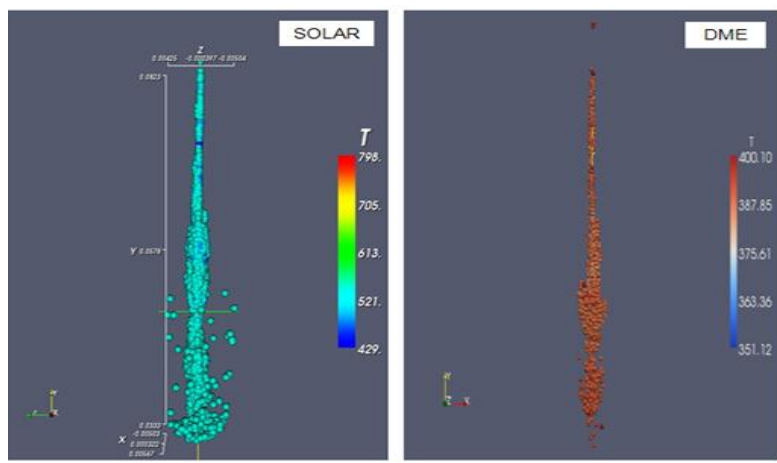

Gambar 5. Pola distribusi temperatur kabut $100 \%$ Solar dan 100\%DME (0,0017 detik, 150 bar $)$

Gambar 6 dan Gambar 7 masing-masing menunjukkan pola distribusi konsentrasi dan temperatur kabut 100\%solar dengan 100\%DME pada tekanan 150 bar selama waktu injeksi 0,0049 detik.
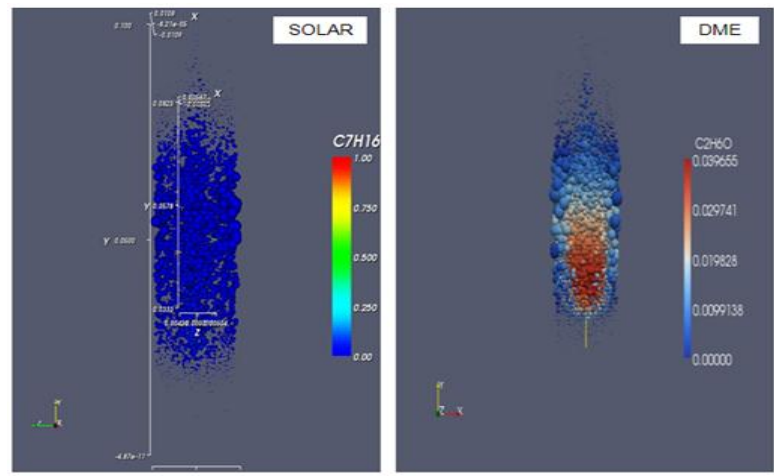

Gambar 6. Pola distribusi konsentrasi kabut $100 \%$ Solar dan $100 \%$ DME $(0,0049$ detik, 150 bar) 

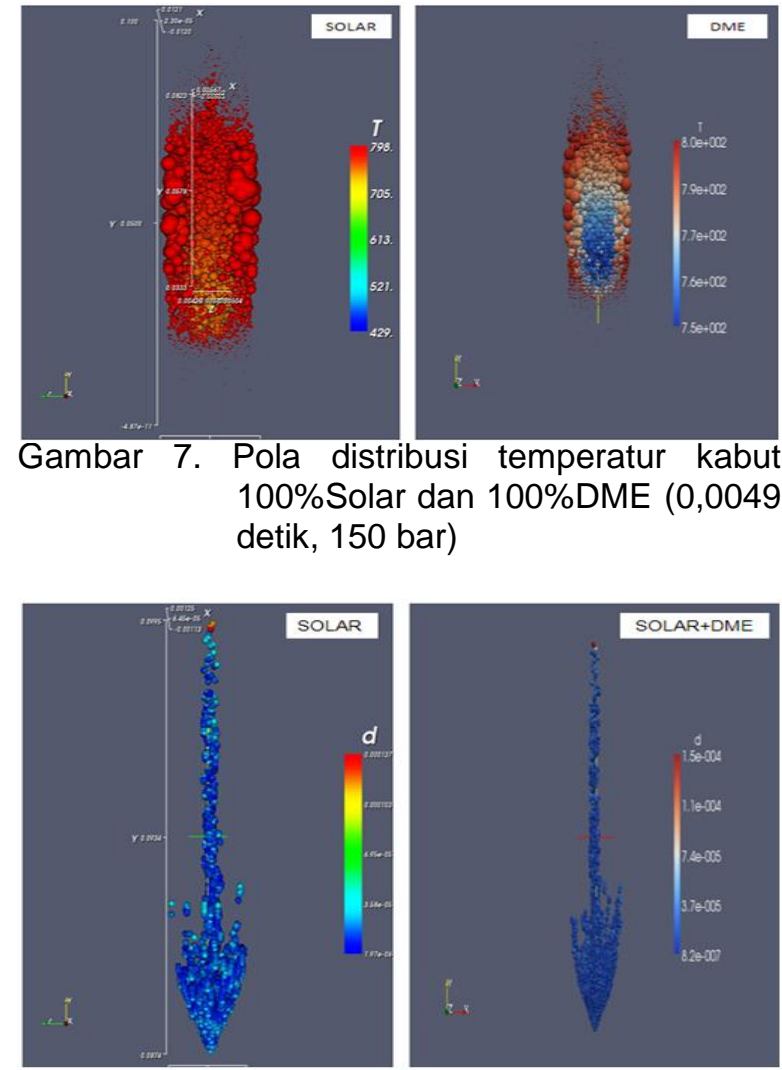

Gambar 8. Pola distribusi ukuran kabut $100 \%$ Solar dan campuran Solar+DME 50/50 (0,0015 detik, 150 bar)

Gambar 8 dan Gambar 9 masing-masing menunjukkan pola distribusi ukuran dan temperatur kabut $100 \%$ solar dengan campuran solar+DME 50/50, pada tekanan 150 bar selama waktu injeksi 0,0015 detik.

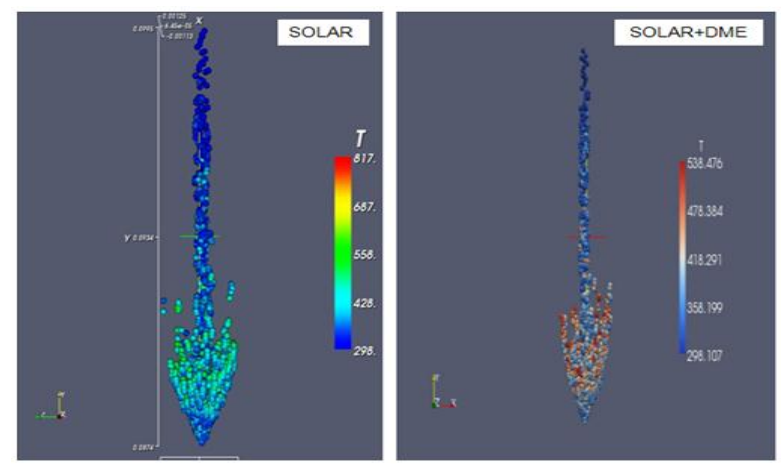

Gambar 9. Pola distribusi temperatur kabut $100 \%$ Solar dan campuran Solar+DME 50/50 (0,0015 detik, 150 bar)

Gambar 10 dan Gambar 11 masing-masing menunjukkan pola distribusi ukuran dan temperatur kabut $100 \%$ solar dengan campuran
Solar+DME 50/50 pada tekanan 150 bar selama waktu injeksi 0,0017 detik.
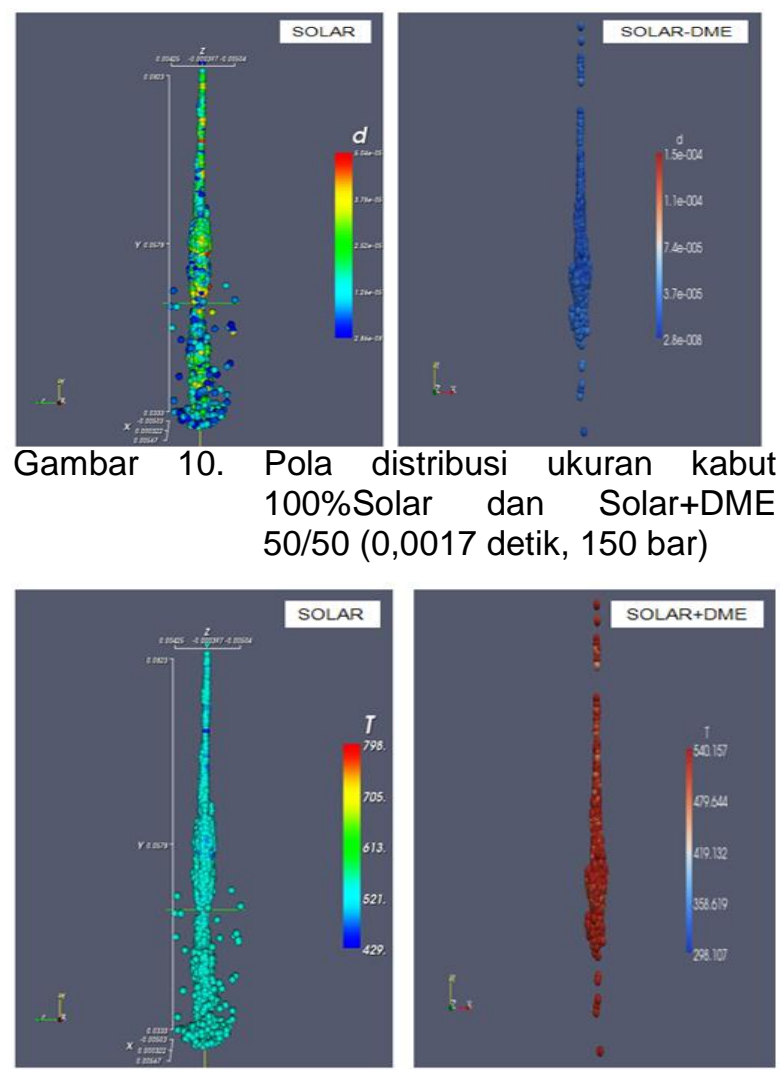

Gambar 11. Pola distribusi temperatur kabut $100 \%$ Solar dan Solar+DME 50/50 (0,0017 detik, 150 bar)

Gambar 12 dan Gambar 13 masing-masing menunjukkan pola distribusi konsentrasi dan temperatur kabut $100 \%$ Solar dengan campuran Solar+DME 50/50 pada tekanan 150 bar selama waktu injeksi 0,0049 detik.

Gambar 14 menunjukkan korelasi konsumsi bahan bakar (gram $/ \mathrm{kWh}$ ) terhadap daya motor (Watt) yang dibangkitkan pada putaran mesin 1500 per menit.

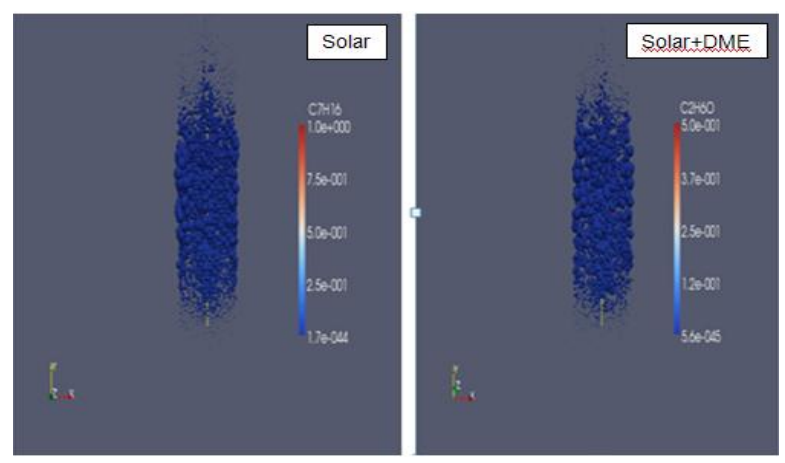

Gambar 12. Pola distribusi konsentrasi kabut $100 \%$ Solar dan Solar+DME 50/50 (0,0049 detik, 150 bar) 

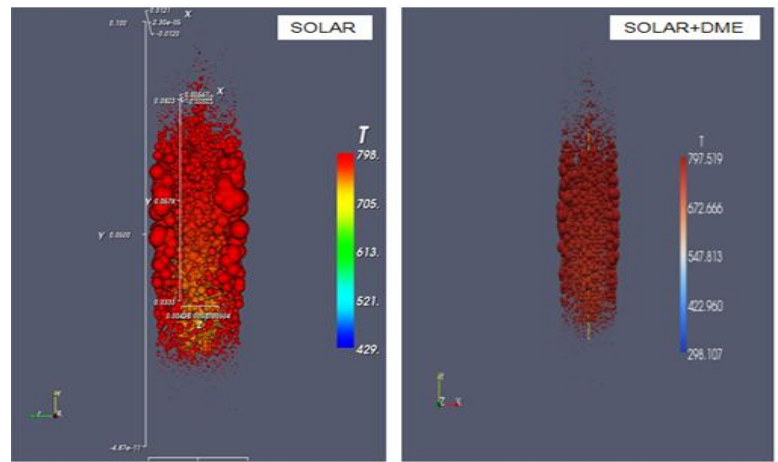

Gambar 13. Pola distribusi temperatur kabut $100 \%$ Solar dan Solar+DME 50/50 (0,0049 detik, 150 bar)

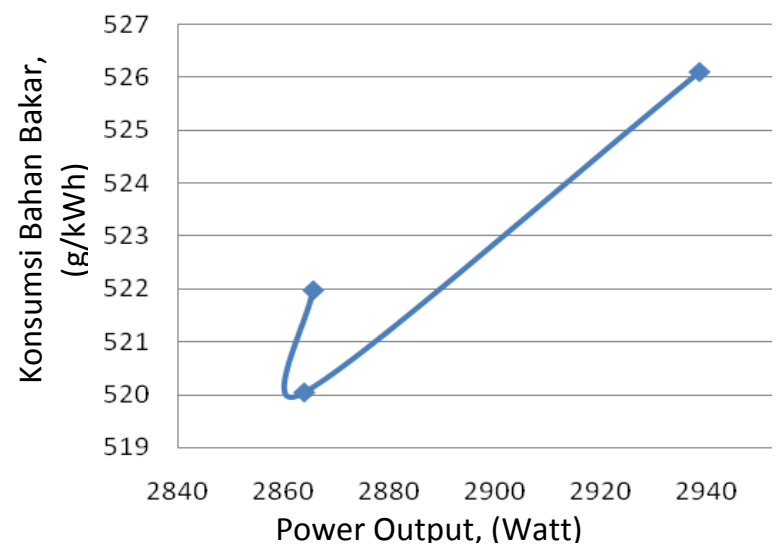

Gambar 14. Korelasi konsumsi bahan bakar terhadap power output (1500 rpm)

\subsection{Pembahasan}

Analisis hasil simulasi atomisasi bahan bakar pada tekanan injeksi 150, 180 dan 235 bar dilakukan terhadap distribusi ukuran, temperatur dan konsentrasi campuran bahan bakar+udara.

\subsubsection{Distribusi ukuran bahan bakar}

Gambar 2 menunjukkan pola distribusi ukuran kabut $100 \%$ Solar dan $100 \%$ DME $(0,0015$ detik, 150 bar), di mana ukuran kabut 100\%DME adalah $1,5.10^{-7} \mathrm{~m} \sim 3,5.10^{-5} \mathrm{~m}$, sedangkan ukuran kabut $100 \%$ Solar berkisar antara $1,97.10$ ${ }^{6} \mathrm{~m} 3,58.10^{-5} \mathrm{~m}$. Sementara pada tekanan 180 bar selama waktu injeksi 0,0015 detik, masingmasing ukuran kabut adalah $2,210^{-8} \mathrm{~m} \sim 3,510^{-}$ ${ }^{5} \mathrm{~m}$ (100\%DME) dan $2,86 \quad 10^{-8} \mathrm{~m} \sim 3,43 \quad 10^{-5} \mathrm{~m}$ (100\%Solar). Sedangkan pada tekanan 235 bar selama waktu injeksi 0,0015 detik, masingmasing ukuran kabut adalah $1,510^{-7} \mathrm{~m} \sim 3,510^{-}$ ${ }^{5} \mathrm{~m}$ (100\%DME) dan $1,97 \quad 10^{-6} \mathrm{~m} \sim 3,58 \quad 10^{-5} \mathrm{~m}$ (100\%Solar). Dengan demikian, distribusi ukuran kabut 100\%DME secara signifikan lebih kecil dibandingkan dengan distribusi ukuran kabut
100\%Solar, karena proses penguapan DME terjadi lebih cepat dibandingkan solar.

Gambar 4 menunjukkan pola distribusi ukuran kabut $100 \%$ Solar dan $100 \%$ DME $(0,0017$ detik, 150 bar), di mana ukuran kabut 100\%DME adalah $2,2.10^{-8} \mathrm{~m} \sim 2,7.10^{-5} \mathrm{~m}$, sedangkan ukuran kabut $100 \%$ Solar berkisar antara 2,86.10 ${ }^{8} \mathrm{~m} \sim 3,7.10^{-5} \mathrm{~m}$. Sementara pada tekanan 180 bar selama waktu injeksi 0,0017 detik, masingmasing ukuran kabut adalah 2,2 $10^{-8} \mathrm{~m} \sim 3,510^{-}$ ${ }^{5} \mathrm{~m}$ (100\%DME) dan 2,86 $10^{-8} \mathrm{~m} \sim 3,43 \quad 10^{-5} \mathrm{~m}$ (100\%Solar). Sedangkan pada tekanan 235 bar selama waktu injeksi 0,0017 detik, masingmasing ukuran kabut adalah $2,210^{-8} \mathrm{~m} \sim 3,510^{-}$ ${ }^{5} \mathrm{~m} \quad\left(100 \%\right.$ DME) dan $2,86 \quad 10^{-8} \mathrm{~m} \sim 1,26 \quad 10^{-5} \mathrm{~m}$ (100\%Solar). Di sini terlihat bahwa kecenderungan .distribusi ukuran kabut $100 \%$ Solar dan $100 \%$ DME pada waktu injeksi selama 0,0017 detik tetap sama dibandingkan dengan distribusi ukuran kabut pada waktu injeksi 0,0015 detik.

Gambar 8 menunjukkan pola distribusi ukuran kabut $100 \%$ Solar dan campuran Solar+DME 50/50 (0,0015 detik, 150 bar), di mana ukuran kabut Solar+DME 50/50 berkisar $8,2.10^{-7} \mathrm{~m} \sim 3,7.10^{-5} \mathrm{~m}$, sedangkan ukuran kabut $100 \%$ Solar berkisar $1,97.10^{-6} \mathrm{~m} \sim 3,58.10^{-5} \mathrm{~m}$. Sementara pada tekanan 180 bar selama waktu injeksi 0,0015 detik, masing-masing ukuran kabut adalah $2,810^{-8} \mathrm{~m} \sim 3,710^{-5} \mathrm{~m}$ (100\%DME) dan $2,86 \quad 10^{-8} \mathrm{~m} \sim 3,43 \quad 10^{-5} \mathrm{~m} \quad$ (100\%Solar). Sedangkan pada tekanan 235 bar selama waktu injeksi 0,0015 detik, masing-masing ukuran kabut adalah 2,8 $10^{-8} \mathrm{~m} \sim 3,710^{-5} \mathrm{~m}$ (100\%DME) dan $\quad 1,97 \quad 10^{-6} \mathrm{~m} \sim 3,54 \quad 10^{-5} \mathrm{~m} \quad$ (100\%Solar). Terlihat bahwa ukuran kabut campuran Solar+DME 50/50 lebih kecil dibandingkan dengan ukuran kabut $100 \%$ Solar, namun perbedaannya tidak sebesar jika dibandingkan dengan 100\%DME. Hal ini karena adanya kandungan $50 \%$ Solar dalam bahan bakar campuran Solar+DME 50/50.

Gambar 10 menunjukkan pola distribusi ukuran kabut $100 \%$ Solar dan campuran Solar+DME 50/50 (0,0017 detik, 150 bar), di mana setelah injeksi. rentang ukuran kabut campuran Solar+DME 50/50 adalah sekitar $2,8.10^{8} \mathrm{~m} \sim 3,7.10^{5} \mathrm{~m}$ sedangkan ukuran kabut $100 \%$ Solar adalah sekitar $2,86.10^{8} \mathrm{~m} \sim 1,26.10^{5} \mathrm{~m}$. Sementara pada tekanan 180 bar selama waktu injeksi 0,0017 detik, masing-masing ukuran kabut adalah 2,8 $10^{-8} \mathrm{~m} \sim 3,7 \quad 10^{-5} \mathrm{~m}$ (campuran Solar+DME 50/50) dan 2,86 $10^{-8} \mathrm{~m} \sim 3,43 \quad 10^{-5} \mathrm{~m}$ (100\%Solar). Sedangkan pada tekanan 235 bar selama waktu injeksi 0,0017 detik, masingmasing ukuran kabut adalah $2,810^{-8} \mathrm{~m} \sim 3,7 \quad 10^{-}$ ${ }^{5} \mathrm{~m}$ (campuran Solar+DME 50/50) dan 2,86 10 ${ }^{8} \mathrm{~m} \sim 1,2610^{-5} \mathrm{~m}$ (100\%Solar). Di sini, perbedaan 
ukuran kabut campuran Solar+DME 50/50 terhadap kabut $100 \%$ solar semakin kecil selama waktu injeksi sekitar 0,0017 detik.

\subsubsection{Distribusi temperatur bahan bakar}

Gambar 3 menunjukkan perbedaan pola distribusi temperatur antara kabut 100\%Solar dan 100\%DME pada tekanan injeksi 150 bar, di mana distribusi temperatur kabut $100 \%$ Solar berkisar $298 \sim 817^{\circ} \mathrm{K}$. Kecenderungan yang sama juga dialami oleh kabut 100\%DME dimana rentang distribusi temperatur sekitar $298 \sim 400^{\circ} \mathrm{K}$ (150 bar) dan $298 \sim 540^{\circ} \mathrm{K}$ (235 bar), sementara distribusi temperatur kabut $100 \%$ Solar maupun $100 \%$ DME pada tekanan injeksi 180 bar memiliki rentang yang sama yaitu $298 \sim 798^{\circ} \mathrm{K}$. D

Distribusi temperatur kabut 100\%DME lebih rendah karena DME memiliki titik didih yang rendah $\left(-25^{\circ} \mathrm{C}\right.$ atau $\left.248^{\circ} \mathrm{K}\right)$ sehingga ketika DME diinjeksikan pada suhu ruang $298^{\circ} \mathrm{K}$ langsung berubah fase menjadi gas. Setelah itu terjadi perpindahan panas dari udara ke DME yang berjalan sangat lambat karena konduktivitas panas DME sangat rendah. Sementara itu, solar yang memiliki titik didih tinggi $\left(>100^{\circ} \mathrm{C}\right)$ ketika pada awal injeksi fase solar masih berupa cairan yang memiliki konduktivitas lebih tinggi dari DME sehingga distribusi temperatur $100 \%$ Solar lebih tinggi.

Gambar 5 menunjukkan pola distribusi temperatur kabut $100 \%$ Solar pada tekanan injeksi 150 bar lebih tinggi $\left( \pm 521^{\circ} \mathrm{K}\right)$ dibandingkan 100\%DME $\left(387 \sim 400^{\circ} \mathrm{K}\right)$, sementara distribusi temperatur kabut $100 \%$ Solar pada tekanan injeksi 235 bar $\left( \pm 521^{\circ} \mathrm{K}\right)$ berada di antara distribusi temperatur 100\%DME $\left(479 \sim 540^{\circ} \mathrm{K}\right)$. Sebaliknya distribusi temperatur kabut $100 \%$ DME pada tekanan 180 bar $\left(673 \sim 796^{\circ} \mathrm{K}\right)$ lebih tinggi daripada distribusi temperatur kabut $100 \%$ Solar $\left(423^{\circ} \mathrm{K}\right)$.

Gambar 7 menunjukkan perkembangan pola kabut $100 \%$ Solar dan $100 \%$ DME pada tekanan injeksi 150 bar ketika nozzle telah berhenti menginjeksi pada kondisi dimana semua kabut $100 \%$ Solar dan $100 \%$ DME telah menjadi fase uap dan telah bercampur dengan udara. Terlihat bahwa kabut $100 \%$ Solar telah menjadi homogen pada temperatur sekitar $798^{\circ} \mathrm{K}$ (150 bar), $797^{\circ} \mathrm{K}$ (180 dan 235 bar) sedangkan temperatur kabut 100\%DME bervariasi $750 \sim 800^{\circ} \mathrm{K}$ (150 dan 180 bar). Pada saat ini kedua bahan bakar menuju fase dimana 100\%Solar dan 100\%DME akan mulai terbakar.

Gambar 9 menunjukkan pola distribusi temperatur kabut $100 \%$ Solar dan campuran Solar+DME 50/50 pada tekanan 150 bar selama waktu injeksi 0,0015 detik, di mana distribusi temperatur kabut 100\%DME dan campuran
Solar+DME 50/50 cenderung lebih rendah $\left(538^{\circ} \mathrm{K}\right)$ dibandingkan temperatur kabut $100 \%$ Solar $\left(817^{\circ} \mathrm{K}\right)$. Kecenderungan serupa terjadi pada tekanan 235 bar, di mana distribusi temperatur kabut campuran Solar+DME 50/50 lebih rendah $\left(797^{\circ} \mathrm{K}\right)$ dibandingkan temperatur kabut $100 \%$ Solar $\left(817^{\circ} \mathrm{K}\right)$. Hal ini dikarenakan oleh titik didih dan konduktivitas panas campuran Solar+DME 50/50 lebih rendah daripada $100 \%$ Solar. Sedangkan distribusi temperatur kabut campuran Solar+DME 50/50 dan $100 \%$ Solar pada tekanan injeksi 180 bar mendekati sama yaitu $798^{\circ} \mathrm{K}$.

Gambar 11 menunjukkan kecenderungan pola distribusi temperatur kabut bahan bakar campuran Solar+DME 50/50 pada tekanan injeksi 150 bar lebih rendah $\left(540^{\circ} \mathrm{K}\right)$ dibandingkan dengan temperatur kabut $100 \%$ Solar $\left(798^{\circ} \mathrm{K}\right)$. Kehadiran $50 \%$ solar dalam campuran Solar+DME 50/50 selain mengakibatkan kenaikan temperatur yang cukup signifikan, yaitu dari sekitar $400^{\circ} \mathrm{K}$ menjadi $540^{\circ} \mathrm{K}$ (campuran Solar+DME 50/50). juga meningkatkan titik didih dan konduktivitas panas dari campuran Solar+DME 50/50.

Gambar 13 menunjukkan pola distribusi temperatur kabut campuran Solar+DME 50/50 pada tekanan injeksi 150 bar $\left(797,5^{\circ} \mathrm{K}\right)$ mendekati pola distribusi temperatur kabut $100 \%$ Solar $\left(798^{\circ} \mathrm{K}\right)$. Sebaliknya, distribusi temperatur kabut campuran Solar+DME 50/50 pada tekanan injeksi 180 dan 235 bar $\left(797,5^{\circ} \mathrm{K}\right)$ sedikit melampaui distribusi temperatur kabut $100 \%$ Solar $\left(797^{\circ} \mathrm{K}\right)$.

\subsubsection{Distribusi konsentrasi campuran bahan bakar+udara}

Gambar 2 menunjukkan bahwa pola kabut 100\%DME akan lebih mudah bercampur dengan udara membentuk campuran homogen yang mudah terbakar.

Gambar 6 menunjukkan pola distribusi konsentrasi $100 \%$ Solar dan 100\%DME ketika berubah fase gas/uap setelah injeksi selama 0,0049 detik pada tekanan 150 bar. Konsentrasi atau fraksi uap $100 \%$ Solar terhadap udara terlihat homogen dan lebih tersebar $(0 \sim 0,04)$, begitu pula hal serupa terjadi pada tekanan injeksi 180 bar. Sementara pada tekanan injeksi 235 bar lebih menyebar (0 1).

Gambar 8 menunjukkan bahwa pola kabut campuran Solar+DME 50/50 akan sedikit lebih mudah bercampur dengan udara secara homogen dibandingkan kabut 100\%Solar dengan udara.

Gambar 12 menunjukkan pola distribusi konsentrasi kabut $100 \%$ Solar dan campuran Solar+DME 50/50 pada tekanan injeksi 150 bar 
yang terjadi beberapa saat setelah proses injeksi selama 0,0049 detik selesai dengan kondisi hampir semua DME dan Solar sudah berubah fase menjadi gas.

Pada tekanan injeksi 180 bar dan 235 bar juga terjadi kecenderungan pola distribusi (temperatur, ukuran, konsentrasi) kabut bahan bakar (100\%Solar, 100\%DME, Solar+DME 50/50) yang serupa dengan tekanan injeksi 150 bar selama variasi waktu injeksi 0,0015 detik, 0,0017 detik dan 0,0049 detik.

\subsubsection{Kinerja mesin diesel}

Hasil uji pengkabutan bahan bakar DME pada tekanan injeksi (185 bar dan 235 bar) di atas tekanan injeksi normal bahan bakar solar (150 bar) mengakibatkan proses penguapan DME lebih cepat. Dilatarbelakangi hal tersebut, maka uji kinerja mesin diesel mengacu pada 3 (tiga) variasi tekanan, yaitu: 185, 120, dan 70 bar.

Hasil pencampuran bahan bakar solar dan DME menghasilkan penurunan kekentalan yang diikuti meningkatnya fraksi massa DME yang tercampur. Kekentalan DME yang dicampur dengan solar dibawah batas yang sudah ditentukan oleh ASTM akan ideal jika campuran $>25 \%$.

Konsumsi bahan bakar campuran DME+Solar 50/50 pada tekanan 70 bar lebih tinggi daripada tekanan 120 dan 185 bar, sementara konsumsi bahan bakar yang terendah adalah pada tekanan 120 bar meskipun perbedaannya tidak signifikan.

Pada tekanan 120 bar mengkonsumsi bahan bakar campuran Solar+DME 50/50 sebesar 520 gram/kWh menghasilkan temperatur gas buang paling rendah $\left(294^{\circ} \mathrm{C}\right)$, namun konsumsi bahan bakar campuran Solar+DME 50/50 sedikit lebih tinggi (522-526 gram/kWh) terjadi peningkatan temperatur gas buang yang mencapai sekitar $300^{\circ} \mathrm{C}$ (70 bar dan 185 bar). Sementara temperatur gas buang yang tertinggi dicapai bahan bakar solar $\left(320^{\circ} \mathrm{C}\right)$, disusul kemudian DME $\left(312^{\circ} \mathrm{C}\right)$.

Power output ialah daya rata-rata 1 phasa antara 3 phasa pembangkitan, di mana korelasi antara konsumsi bahan bakar dengan power output seperti terlihat pada Gambar 14 menunjukkan bahwa penggunaan bahan bakar campuran Solar+DME 50/50 memberikan konsumsi bahan bakar terendah sementara power output yang dibangkitkan sebesar 2975 Watt. Konsumsi bahan bakar 100\%DME meningkat sementara power output yang dibangkitkan hampir sama dengan campuran Solar+DME 50/50, sementara itu penggunaan bahan bakar 100\%solar pada rpm mesin yang sama memberikan power output terbesar yang mencapai 2940 watt.

\section{KESIMPULAN}

Berdasarkan hasil analisis simulasi proses injeksi bahan bakar solar, DME dan campuranya pada tekanan 150 bar, 180 bar dan 235 bar dapat disimpulkan sebagai berikut.

Pola distribusi temperatur kabut solar secara umum lebih tinggi daripada DME pada awal maupun akhir injeksi, demikian juga distribusi ukuran kabut solar lebih besar dibandingkan dengan DME, sehingga DME akan lebih cepat menguap dan bercampur udara secara homogen.

Temperatur pembakaran DME dan temperatur gas buangnya cenderung lebih rendah daripada solar.

Pembakaran DME berlangsung lebih cepat dan sempurna, karena selain DME memiliki cetan number $\left(\mathrm{CN}_{\mathrm{DME}}=55-64\right)$ lebih tinggi daripada solar $\left(\mathrm{CN}_{\text {Solar }}=49-55\right)$ juga ukuran kabut DME lebih kecil dibandingkan solar, sehingga bercampur dengan udara lebih sempurna.

Periode waktu injeksi lebih lama dibandingkan dengan bahan bakar solar, karena pada fase cair DME mempunyai kerapatan dan nilai kalor yang rendah, sehingga memerlukan volume DME lebih banyak (minimal 1,8 kali dari volume bahan bakar solar) untuk memasok energi dalam menginjeksikan ke dalam silinder.

Kerja kompresi pompa bahan bakar DME lebih berat, karena DME memiliki kerapatan lebih rendah dan kemampuan menekan yang tinggi dibandingkan dengan solar.

Terjadi peningkatan temperatur pada pompa injeksi menunjukkan kerja mesin yang berat akibat kavitasi dan/atau pelumasan kurang baik. Dalam pengujian ini menggunakan aditif pelumas $1 \%$ castor oil.

DME layak sebagai bahan bakar pengganti solar pada mesin diesel dengan menambahkan pelumas $2-5 \%$ aditif.

Penggunaan bahan bakar campuran Solar+DME 50/50 memberikan konsumsi bahan bakar terendah sementara power output yang dibangkitkan 2.975 watt.

Konsumsi bahan bakar 100\%DME meningkat dengan menghasilkan power output yang hampir sama seperti campuran Solar+DME 50/50, sementara itu penggunaan bahan bakar $100 \%$ solar pada putaran mesin (rpm) yang sama memberikan power output terbesar yang mencapai 2.940 watt.

Sistem injeksi bahan bakar harus diberikan tekanan, termasuk pada tangki penyimpan seperti halnya tangki LPG yang bertekanan, hal 
ini mengingat sistem bahan bakar bertekanan tertutup karena titik didih DME rendah $\left(-25,1^{\circ} \mathrm{C}\right.$, 1 atm).

Pada sistem injeksi bahan bakar berpotensi kavitasi, karena DME memiliki tekanan penguapan tinggi, sehingga perlu tekanan 1,23,0 MPa untuk mengalirkan DME dari tangki penyimpanan melalui pipa ke ruang bakar agar pengoperasian injeksi bahan bakar stabil.

Sifat pelumasan DME yang lebih rendah daripada solar menjadikan permasalahan saat digunakan sebagai bahan bakar, sehingga perlu ditingkatkan hingga 2000 ppm dengan menambahkan aditif pelumas, seperti lubrizol (1000 ppm), Hitec 560 (100 ppm) dan infineum R655 (500 ppm).

Rentan kebocoran di antara plunger dan barrel mengingat DME memiliki nilai kekentalan yang rendah.

Rentan kerusakan pada material sealing dan komponen plastik lainnya karena DME tidak kompatibel dengan elastomer, sehingga DME harus ditampung dalam tangki bertekanan ( 6 bar, $20^{\circ} \mathrm{C}$ ) seperti halnya LPG.

\section{DAFTAR PUSTAKA}

Boedoyo M.S., Bambang S.R., Taufik Y., Wargiantoro P., Suharyono, 2010. Kajian Pemanfaatan Dimethyl Ether Sebagai Bahan Bakar Pada Mesin Diesel.. Nopember 2010, 29-37.

Elana M. Chapman, 2003. Annual Technical Progress Report for Project Entitled, Impact of DME-Diesel Fuel Blend Properties on Diesel Fuel Injection Systems. May 16, 2002 - May 15, 2003, Report Issue Date: June 2003, The Energy Institute University Park, The Pennsylvania State University.

Hyun Kyu Suh, Chang Sik Lee, 2007. Experimental And Analytical Study On The Spray Characteristics Of Di-methyl Ether (DME) And Diesel Fuels Within A Commonrail Injection System In $A$ Diesel Engine. Eisevier, ScienceDirect, Mechanical Engineering, Hanyang University, 17 Haengdang-dong, Available on 5 July 2007.

Troy A. Semelsberger, Rodney L. Borup, Howard L. Greene. 2006. Di-methyl Ether (DME) As An Alternative Fuel. Journal of Power Sources, Volume 156, Issue 2, June 2006, 497-511. 